\title{
The Construct Validation of a Questionnaire of Social and Cultural Capital
}

\author{
Reza Pishghadam (Corresponding author) \\ English Department, Ferdowsi University of Mashhad \\ PO box 91779-48974, Park Square, Ferdowsi University Mashhad, Iran \\ E-mail: rpishghadam@yahoo.com \\ Mohsen Noghani \\ Department of Sociology, Ferdowsi University of Mashhad \\ PO box 91779-48974, Park Square, Ferdowsi University Mashhad, Iran \\ E-mail: mohsennoghani@yahoo.com \\ Reza Zabihi \\ English Department, Ferdowsi University of Mashhad \\ PO box 91779-48974, Park Square, Ferdowsi University Mashhad, Iran \\ E-mail: zabihi@hotmail.com
}

Received: February 12, 2011

Accepted: February 28, 2011

Published: December 1, 2011

doi:10.5539/elt.v4n4p195

URL: http://dx.doi.org/10.5539/elt.v4n4p195

\begin{abstract}
The present study was conducted to construct and validate a questionnaire of social and cultural capital in the foreign language context of Iran. To this end, a questionnaire was designed by picking up the most frequently-used indicators of social and cultural capital. The Factorability of the intercorrelation matrix was measured by two tests: Kaiser-Meyer-Olkin test of Sampling Adequacy (KMO) and Bartlett's Test of Sphericity. The results obtained from the two tests revealed that the factor model was appropriate. To validate the questionnaire, Exploratory Factor Analysis (EFA) was performed. The application of the Principle Component Analysis to the participants' responses resulted in 14 extracted factors accounting for $69 \%$ of the variance. The results obtained from the Scree Test indicated that a five-factor solution might provide a more parsimonious grouping of the items in the questionnaire. The rotated component matrix indicated the variables loaded on each factor so that the researchers came up with the new factors, i.e., social competence, social solidarity, literacy, cultural competence, and extraversion. Finally, statistical results were discussed and suggestions were made for future research.
\end{abstract}

Keywords: Construct validity, Social capital, Cultural capital

\section{Introduction}

The concepts of social and cultural capital, put forward by Bourdieu (1977; 1986; Bourdieu \& Johnson, 1993; Bourdieu, Passeron, \& Martin, 1996), have prompted many research projects concerning different aspects of individuals' lives. For capital is not only economic but is also social and cultural. In other words, like economic capital, the higher distribution of cultural and social capital among a particular social class can be a source of power defining the chances of profit in a given field. That is to say, the more one possesses social and cultural capital, the more successful one may be in a specific area.

In their comprehensive review of literature, Lareau and Weininger (2003) provided different definitions of cultural capital. Likewise, while Coleman (1988) approached social capital from an educational perspective, and asserted that "all social relations and social structures facilitate some forms of social capital" (p. S105), Bourdieu (1986) took a sociological perspective, and tried to view social capital as a tool in the hands of a few elite. The arguments posited by Bourdieu and Coleman, nevertheless, have germinated many research projects to explore the possible relationship of social capital with other variables. According to Portes (2000), as a concept social capital has been 
"one of the most successful 'exports' from sociology to other social sciences and to public discourse during the last two decades" (p. 1). Dika and Singh (2002), based on their critical review on social capital, declared that the concept has been widely used in anthropology, business, economics, education, development/planning, political science and sociolinguistics. In the area of education, for example, researchers agree on the importance of studying educational institutions in social contexts by examining how individuals' different social and cultural experiences affect their educational outcomes (e.g., Bassani, 2006; Crosnoe, 2004; De Graaf, De Graaf, \& Kraaykamp, 2000; DiMaggio, 1982; Eng, 2009; Israel, Beaulieu, \& Hartless, 2001; Kim \& Schneider, 2005; Merenluoto, 2009; Nakhaie \& Curtis, 1998; Prado, 2009; Sandefur, Meier, \& Hernandez, 1999; Schlee, Mullis, \& Shriner, 2009; Tramonte \& Willms, 2010; Wells, 2008). All of these studies concur that social and cultural capital are of paramount importance in education and worthy of consideration by researchers and practitioners. However, it seems that, the operationalisation of social and cultural capital has not yet received substantial attention.

It seems that designing a scale of social and cultural capital can pave the way for other researchers to apply Bourdieu's ideas to different contexts, coming up with different notions and findings. This instrument can help researchers and practitioners to measure objectively the impact of social and cultural capital on learners' motivation, performance, attainment, social division, identity construction, etc. in the realm of education.

Therefore, the dearth of a scale for measuring cultural and social capital has led us to undertake an investigation into constructing a questionnaire of social and cultural capital and validating it through its application to university EFL learners in the context of Iran.

Purpose of the present study:

Due to the importance of social and cultural capital concepts in education, this study intends to construct and validate a questionnaire of social and cultural capital in the context of Iran. We hope our instrument can deepen and enrich our understanding of social and cultural capital constructs and help researchers conduct more empirical research into the nature of social and cultural capital and different issues in education. With that in mind, this study investigates the following research question:

Q 1: What factors are measured by the Social and Cultural Capital Questionnaire when examined with EFL students?

\section{Method}

\subsection{Participants}

One hundred and twenty eight EFL learners participated in this study, comprised of 86 females and 42 males between the ages of 19 and $33(\mathrm{M}=21.7, \mathrm{SD}=2.02)$. All of the participants were university students attending three universities in Iran, majoring in English Literature (54), English Teaching (48), and English Translation (25). They were all in their second year and passed their language proficiency courses.

\subsection{Instrumentation}

In order to measure the participants' levels of social and cultural capital, we had to design a questionnaire. Since, to our best knowledge, nobody has designed a questionnaire of social and cultural capital that takes a comprehensive account of the indicators of both social and cultural capital, the questionnaire was first constructed and then validated through its application to EFL learners.

\subsection{Procedures}

The procedures followed in this study comprise designing and validating the questionnaire. To design the questionnaire, the researchers elicited the indicators of social and cultural capital from two collections of previous studies (Dica \& Singh, 2002; Lareau \& Weininger, 2003). Having obtained the opinions of three specialists in the sociology of education, the researchers picked up among several social and cultural capital indicators those which were most relevant and applicable to the Iranian EFL context. This resulted in a checklist of social and cultural capital indicators based on which the items of the questionnaire were constructed. Joint consultations were held to make the best items out of the previously made checklist and also to revise the items. The newly-developed questionnaire was then submitted to two experts in the field of sociology of education, and they were asked to evaluate its content and also to give their opinions so that the researchers could remove possible deficiencies. Moreover, 8 EFL learners whose characteristics were similar to those of the target population were asked to read the revised questionnaire and to express their understanding of it; in this way, the researchers were able to remove any ambiguity which might have led to misunderstandings on the part of the participants. The questionnaire comprises 43 items which are measured with the use of two subscales: Social capital and Cultural capital. The items are scored according to the Likert- type scale of five points ranging from (1) "strongly disagree" to (5) "strongly agree". 


\subsection{Data analysis}

The internal consistency of the whole questionnaire was measured with the Cronbach Alpha reliability estimate. Moreover, using Cronbach Alpha, the reliability of each factor constructing the validated questionnaire was also examined.

To validate the questionnaire, Exploratory Factor Analysis (EFA) was used. First, PCA extracted the underlying factors by calculating the eigenvalues of the matrix greater than 1.0. The Scree test was used in order to decide about the number of factors to retain for rotation. For conducting factor rotation, Varimax (orthogonal rotation) with Kaiser Criterion was used. The result was a rotated component matrix and a transformation matrix. The rotated component matrix indicated the variables loaded on each factor so that the researchers came up with the new factors.

\section{Results}

\subsection{Reliability of the social and cultural capital questionnaire}

Cronbach Alpha estimated the reliability of the whole items as 0.88 . After factor rotation was inspected, the number of items was reduced to 42 . All of the five factors yielded good reliability estimates ranging from 0.51 to 0.89 (Table $1)$.

\subsection{Construct validity}

The Factorability of the intercorrelation matrix was measured by two tests: Kaiser-Meyer-Olkin test of Sampling Adequacy (KMO) and Bartlett's Test of Sphericity. The results obtained from the two tests revealed that the factor model was appropriate (Table 2).

The construct validity of the Social and Cultural Capital Questionnaire was examined through Exploratory Factor Analysis (EFA). PCA extracted 14 factors with eigenvalues greater than 1.0 which accounted for $69 \%$ of the variance.

The results obtained from the Scree Test indicated that a five-factor solution might provide a more suitable grouping of the items in the questionnaire.

The researchers, then, inspected orthogonal rotation. The result of Varimax with Kaiser Normalization was a rotated component matrix. The results of this analysis are shown in Table 3. The results indicated that the first factor consisted of 15 items. The second factor consisted of 11 items. Factor 3 consisted of 6 items. Factor 4 consisted of 7 items and items 18, 19, and 25 made up the fifth factor. The total number of items was 42 .

Finally, the researchers analyzed the items comprising each factor and named the five factors as Social Competence, Social Solidarity, Literacy, Cultural Competence, and Extraversion. Items representing each factor are displayed in Table 4 and 5, and the validated questionnaire is given in Table 6. Although the results of Exploratory Factor Analysis (EFA) have identified 5 separate factors, the underlying subscales measured in this questionnaire are Social Capital (consisting of social competence, social solidarity, and extraversion) and Cultural Capital (consisting of literacy and cultural competence).

\section{Discussion}

This study sought to find out the reliability and validity of the Social and Cultural Capital Questionnaire when examined with EFL students. The results of this analysis were used to name each factor. The reasons for the selection of such names are explained below.

\subsection{Social competence}

Social competence is the label for the first factor which consists of 15 items. As it is shown in Appendix E, items 2, $3,4,8,9,10,11,14$, and 15 measure learners' level of parental involvement in general. Items 1,5 , and 6 specifically test mothers' engagement with the learners' activities. Items 12 and 13 measure the learners' participation in school activities and extracurricular activities, respectively, and item 7 refers to the learners' feeling with regard to their ability to get help from others for performing their activities.

\subsection{Social solidarity}

The second factor is called Social Solidarity which refers to the ties in a society, or social relations, which bind people to one another. This factor consists of 11 items. Items 1, 6 and 7 measure the amount of talk that goes on between learners and their parents or other adults regarding issues like job and education. The learners' tendency to get involved in activities designed for young people is measured by item 2, while items 3 and 4 test the quality of the learners' peers and the quality of their past educational settings. Items 5,8 and 9 test the strength of ties that learners have with their parents, the community, and their peers respectively, and items 10 and 11 measure the strength of ties that parents have with each other and the total intimacy inherent in the family environment. 


\subsection{Literacy}

Factor 3 which is known as Literacy comprises 6 items. Items 1 and 2 measure the learners' reading and knowing about literature while item 4 tests learners' general attitudes towards reading. Items 3 and 6 refer to the learners' having, buying or borrowing books, and item 5 tests parents' degree of encouragement with regard to their children's reading behavior.

\subsection{Cultural competence}

Cultural competence is the label selected by the researchers for the fourth factor of the questionnaire which includes 7 items. Item 1 asks to what extent learners enjoy listening to classical music. Item 2 implies a self-image on the part of learners of whether they think they are cultured or not. Item 3 tests the learners' knowledge about famous music composers. Item 4 refers to the frequency of learners' visiting museums, theaters, or attending at concerts and item 5 measures their tendency to attend symphony concerts. Item 6 asks whether learners used to take art classes outside of school in the past, while item 7 tests learners' ability in using language.

\subsection{Extraversion}

The last factor of the questionnaire is referred to as Extraversion which is referred to as a tendency on the part of people to enjoy human interactions and to take pleasure in activities that involve large social gatherings. This factor comprises 3 items which ask learners whether they visit their siblings, grandparents, and friends weekly.

The value of this research lies in constructing a social and cultural capital research instrument and in helping researchers and practitioners interested in Bourdieu's ideas to employ the scale in the field of language learning. We have utilized exploratory factor analysis as an efficient tool for determining the underlying factors of the instrument. The results have revealed that five factors represent the underlying structure of social and cultural capital instrument. These factors were labeled as: Social competence, Social solidarity, Literacy, Cultural competence, and Extraversion.

It is our hope that future research will lead to further evaluation and improvement of this instrument. Researchers should continue to carry out thorough assessment of the psychometric properties of the instrument designed to measure social and cultural capital. Only after the true factor structure of the social and cultural capital instrument has been examined, can researchers confidently assert conclusions about the role of these variables in language learning.

In the end, researchers are recommended to examine objectively the relationship between social and cultural capital and other related variables such as: literacy, motivation, social division, or identity formation. These variables seem to be highly related to social and cultural factors. Finding any association between these variables and social and cultural capital helps us have a better understanding of the role of these socio-cultural factors in education.

\section{Acknowledgements}

We gratefully acknowledge the project reported here was supported by a grant-in-aid of research from Ferdowsi University of Mashhad in 2010 without which this research would not have been possible. Besides, we announce the study has been a part of research which has been conducted in Mashhad, Iran, in 2010.

\section{References}

Bassani, C. (2006). A test of social capital theory outside of the American context: Family and school social capital and youths' math scores in Canada, Japan, and the United States. International Journal of Educational Research, 45(6), 380-403. http://dx.doi.org/10.1016/j.ijer.2007.03.001

Bourdieu, P. (1977). The economics of linguistic exchanges. Social Science Information, 16, 645-668. http://dx.doi.org/10.1177/053901847701600601

Bourdieu, P. (1986). The forms of capital. In: J. G. Richardson (ed.), Handbook for theory and research for the sociology of education. New York: Greenwood Press. pp. 241-258

Bourdieu, P., \& Johnson, R. (1993). The field of cultural production: Essays on art and literature. New York: Columbia University Press.

Bourdieu, P., Passeron, J., \& Martin, M.S. (1996). Academic discourse: Linguistic misunderstanding and professorial power. California: Stanford University Press.

Coleman, J. S. (1988). Social capital in the creation of human capital. American Journal of Sociology, 94, S95-S120 Crosnoe, R. (2004). Social capital and the interplay of families and schools. Journal of Marriage and Family, 66, 267-280. http://dx.doi.org/10.1111/j.1741-3737.2004.00019.x 
De Graaf, N. D., De Graaf, P. M., \& Kraaykamp, G. (2000). Parental cultural capital and educational attainment in the Netherlands: A refinement of the cultural capital perspective. Sociology of Education, 73(2), 92-111

Dica, S. L., \& Singh, K. (2002). Applications of social capital in educational literature: A critical synthesis. Review of Educational Research, 72, 31-60

DiMaggio, P. (1982). Cultural capital and school success: The impact of status culture participation on the grades of U.S. high school students. American Sociological Review, 47, 189-201

Eng, S. (2009). Social capital and academic achievement among children in Cambodia: A close look at family. Doctoral dissertation. Texas Tech University, Texas.

Israel, G. D., Beaulieu, L. J., \& Hartless, G. (2001). The influence of family and community social capital on educational achievement. Rural Sociology, 66, 43-68

Kim, D. H., \& Schneider, B. (2005). Social capital in action: Alignment of parental support in adolescents' transition to postsecondary education. Social Forces, 84, 1181-1206. http://dx.doi.org/10.1353/sof.2006.0012

Lareau, A., \& Weininger, E. B. (2003). Cultural capital in educational research: A critical assessment. Theory and Society, 32, 567-606

Merenluoto, S. (2009). The connection of cultural capital with success in master's degree programs in Finnish higher education. Research on Finnish Society, 2, 29-38

Nakhaie, M. R., \& Curtis, J. (1998). Effects of class positions of parents on educational attainment of daughters and sons. The Canadian Review of Sociology and Anthropology, 35(4), 483-515

Portes, A. (2000). The two meanings of social capital. Sociological Forum, 15(1), 1-12

Prado, J. M. (2009). Comparing educational trajectories of two Chinese students and one Latina student, a social capital approach. The High School Journal, 92, 14-27

Sandefur, G., Meier, A., \& Hernandez, P. (1999). Families, social capital and educational continuation. CDE Working Paper No. 99-19: Center for Demography and Ecology. Madison, WI: University of Wisconsin-Madison.

Schlee, B. M., Mullis, A. K., \& Shriner, M. (2009). Parents social and resource capital: Predictors of academic achievement during early childhood. Children and Youth Services Review, 31, 227-234. http://dx.doi.org/10.1016/j.childyouth.2008.07.014

Tramonte, L., \& Willms, J. D. (2010). Cultural capital and its effects on education outcomes. Economics of Education Review, 29, 200-213

Wells, R. (2008). The effects of social and cultural capital on student persistence. Community College Review, 36, 25-46. http://dx.doi.org/10.1177/0091552108319604

Table 1. Reliability of each factor

\begin{tabular}{|c|c|c|}
\hline Factors & Cronbach's Alpha & N of Items \\
\hline Factor 1 & .895 & 15 \\
\hline Factor 2 & .751 & 11 \\
\hline Factor 3 & .689 & 6 \\
\hline Factor 4 & .656 & 7 \\
\hline Factor 5 & .518 & 3 \\
\hline
\end{tabular}

Table 2. KMO and Bartlett's Test

\begin{tabular}{|c|c|c|}
\hline \multicolumn{3}{|l|}{ KMO and Bartlett's Test } \\
\hline \multicolumn{2}{|c|}{ Kaiser-Meyer-Olkin Measure of Sampling Adequacy } & .688 \\
\hline \multirow[t]{3}{*}{ Bartlett's Test of Sphericity } & Approx. Chi-Square & $2.012 \mathrm{E} 3$ \\
\hline & df & 903 \\
\hline & Sig. & .000 \\
\hline
\end{tabular}


Table 3. Rotated components obtained via Principal Component Analysis and their loadings

\begin{tabular}{|l|l|l|l|l|}
\hline Component 1 & Component 2 & Component 3 & Component 4 & Component 5 \\
\hline $20=.80$ & $42=.63$ & $2=.72$ & $4=.63$ & $18=.68$ \\
$32=.75$ & $37=.62$ & $11=.62$ & $12=.63$ & 19.56 \\
$31=.75$ & $43=.62$ & $9=.59$ & $6=.62$ & $25=.43$ \\
$23=.73$ & $15=.61$ & $7=.54$ & $1=.49$ & \\
$36=.70$ & $40=.55$ & $5=.52$ & $8=.46$ & \\
$22=.66$ & $14=.50$ & $10=.38$ & $3=.43$ & \\
$21=.61$ & $41=.45$ & & $28=.42$ & \\
$17=.59$ & $26=.43$ & & & \\
$29=.51$ & $30=.42$ & & & \\
$33=.48$ & $38=.32$ & & & \\
$34=.48$ & $27=.30$ & & & \\
$13=.48$ & & & & \\
$35=.42$ & & & & \\
$39=.41$ & & & & \\
$24=.34$ & & & & \\
\hline
\end{tabular}

Rotation Method: Varimax with Kaiser Normalization

Table 4. Five factors of the questionnaire

\begin{tabular}{|l|l|l|l|}
\hline$\#$ areas & Statements & N of items & Percentage \\
\hline 1. Social competence & $19,31,30,22,35,21,20,16,28,32,33,13,34,38,23$ & 15 & 36 \\
\hline 2. Social solidarity & $41,36,42,15,39,14,40,25,29,37,26$ & 11 & 26 \\
\hline 3. Literacy & $2,11,9,7,5,10$ & 6 & 14 \\
\hline 4. Cultural competence & $4,12,6,1,8,3,27$ & 7 & 17 \\
\hline 5. Extraversion & $17,18,24$ & 3 & 7 \\
\hline & Total & 42 & 100 \\
\hline
\end{tabular}

Table 5. The factors of Social and Cultural Capital Questionnaire
Factor 1: Social Competence
1. My mother used to get involved in my primary schooling.
2. My parents usually get involved in my daily activities.
3. My parents used to help me with my homework regularly.
4. I frequently perform activities together with my parents.
5. My mom used to encourage me in my school activities regularly.
6. My mom used to attend school meetings regularly.
7. I feel I have a strong help network for my activities.
8. At home, my parents keep track of my progress.
9. My parents used to volunteer for school projects.
10. My parents used to have a regular connection with my school.
11. My parents know parents of my friends.
12. I used to participate in school activities regularly. 
13. I used to participate in extracurricular activities.

14. My parents used to monitor my homework regularly.

15. My parents used to have a say in school policy.

\section{Factor 2: Social Solidarity}

1. I regularly talk with my parents.

2. I like to get involved in activities designed for young people.

3. I have friends with high educational expectations.

4. I had an excellent school with high quality.

5. My parents know where I am, what I do.

6. I usually talk about job/education with family.

7. I usually talk about job/education with other adults.

8. I feel I have strong ties with the community.

9. I feel I have strong ties with my peers.

10. My parents have strong ties with each other.

11. We have an intimate home environment.

\section{Factor 3: Literacy}

1. I enjoy reading literature.

2. I know a lot about literature.

3. I frequently buy/borrow books.

4. I enjoy reading (in general).

5. As a child, my parents regularly encouraged me to read.

6. We have lots of books at home.

\section{Factor 4: Cultural Competence}

1. I enjoy listening to classical music.

2. I am a cultured person.

3. I know all famous music composers.

4. I frequently visit museums, theaters, or attend concerts.

5. I like to attend symphony concerts.

6. I used to take art or music classes outside school.

7. I am highly proficient in using language.

Factor 5: Extraversion

1. I see my siblings weekly.

2. I see my grandparents weekly.

3. I see my friends weekly. 
Table 6. Social and Cultural Capital Questionnaire (SCCQ)

\begin{tabular}{|c|c|c|c|c|c|c|}
\hline No. & Statement & SD & D & $\mathbf{U}$ & $\mathbf{A}$ & SA \\
\hline 1 & I enjoy listening to classical music. & 1 & 2 & 3 & 4 & 5 \\
\hline 2 & I enjoy reading literature. & 1 & 2 & 3 & 4 & 5 \\
\hline 3 & I am a cultured person. & 1 & 2 & 3 & 4 & 5 \\
\hline 4 & I know all famous music composers. & 1 & 2 & 3 & 4 & 5 \\
\hline 5 & I know a lot about literature. & 1 & 2 & 3 & 4 & 5 \\
\hline 6 & I frequently visit museums, theaters, or attend at concerts. & 1 & 2 & 3 & 4 & 5 \\
\hline 7 & I frequently buy/borrow books. & 1 & 2 & 3 & 4 & 5 \\
\hline 8 & I like to attend symphony concerts. & 1 & 2 & 3 & 4 & 5 \\
\hline 9 & I enjoy reading (in general). & 1 & 2 & 3 & 4 & 5 \\
\hline 10 & When a child, my parents regularly encouraged me to read. & 1 & 2 & 3 & 4 & 5 \\
\hline 11 & We have lots of books at home. & 1 & 2 & 3 & 4 & 5 \\
\hline 12 & I used to take art or music classes outside of school. & 1 & 2 & 3 & 4 & 5 \\
\hline 13 & My mother used to get involved in my primary schooling. & 1 & 2 & 3 & 4 & 5 \\
\hline 14 & I regularly talk with my parents. & 1 & 2 & 3 & 4 & 5 \\
\hline 15 & I like to get involved in activities designed for young people. & 1 & 2 & 3 & 4 & 5 \\
\hline 16 & My parents usually get involved in my daily activities. & 1 & 2 & 3 & 4 & 5 \\
\hline 17 & I see my siblings weekly. & 1 & 2 & 3 & 4 & 5 \\
\hline 18 & I see my grandparents weekly. & 1 & 2 & 3 & 4 & 5 \\
\hline 19 & My parents used to help me with my homework regularly. & 1 & 2 & 3 & 4 & 5 \\
\hline 20 & I frequently perform activities together with my parents. & 1 & 2 & 3 & 4 & 5 \\
\hline 21 & $\begin{array}{l}\text { My mom used to encourage me in my school activities } \\
\text { regularly. }\end{array}$ & 1 & 2 & 3 & 4 & 5 \\
\hline 22 & My mom used to attend school meetings regularly. & 1 & 2 & 3 & 4 & 5 \\
\hline 23 & I feel I have a strong help network for my activities. & 1 & 2 & 3 & 4 & 5 \\
\hline 24 & I see my friends weekly. & 1 & 2 & 3 & 4 & 5 \\
\hline 25 & I have friends with high educational expectations. & 1 & 2 & 3 & 4 & 5 \\
\hline 26 & I had an excellent school with high quality. & 1 & 2 & 3 & 4 & 5 \\
\hline 27 & I am highly proficient in using language. & 1 & 2 & 3 & 4 & 5 \\
\hline 28 & At home, my parents keep track of my progress. & 1 & 2 & 3 & 4 & 5 \\
\hline
\end{tabular}




\begin{tabular}{|l|l|l|l|l|l|l|}
\hline 29 & My parents know where I am, what I do. & 1 & 2 & 3 & 4 & 5 \\
\hline 30 & My parents used to volunteer for school projects. & 1 & 2 & 3 & 4 & 5 \\
\hline 31 & My parents used to have a regular connection with my school. & 1 & 2 & 3 & 4 & 5 \\
\hline 32 & My parents know parents of my friends. & 1 & 2 & 3 & 4 & 5 \\
\hline 33 & I used to participate in school activities regularly. & 1 & 2 & 3 & 4 & 5 \\
\hline 34 & I used to participate in extracurricular activities. & 1 & 2 & 3 & 4 & 5 \\
\hline 35 & My parents used to monitor my homework regularly. & 1 & 2 & 3 & 4 & 5 \\
\hline 36 & I usually talk about job/education with family. & 1 & 2 & 3 & 4 & 5 \\
\hline 37 & I usually talk about job/education with other adults. & 1 & 2 & 3 & 4 & 5 \\
\hline 38 & My parents used to have a say in school policy. & 1 & 2 & 3 & 4 & 5 \\
\hline 39 & I feel I have strong ties with the community. & 1 & 2 & 3 & 4 & 5 \\
\hline 40 & I feel I have strong ties with my peers. & 1 & 2 & 3 & 4 & 5 \\
\hline 41 & My parents have strong ties with each other. & 1 & 2 & 3 & 4 & 5 \\
\hline 42 & We have an intimate home environment. & 2 & 3 & 4 & 5 \\
\hline
\end{tabular}

* SD = Strongly Disagree; D = Disagree; U = Undecided; A = Agree; SA = Strongly Agree 